\title{
Development of multiple choice questions' instructional plan for the nursing educators
}

\author{
Azza Fathi Ibrahim* \\ Nursing Education Departement, Faculity of Nursing, Alexandriea University, Alexandriea, Egypt
}

Received: March 12, 2019

DOI: $10.5430 /$ jnep.v9n9p12
Accepted: May 14, 2019

Online Published: June 3, 2019

\begin{abstract}
Multiple-choice questions (MCQs) are commonly employed tests configuration in healthcare sciences for several years. They are efficient means for formative and summative evaluation of the students in nursing education. If the MCQs are designed competently, it will be a resourceful measurement for a valid assessment of the nursing students. The present study aimed to evaluate the construction quality of MCQs and its common item flaws in core nursing subjects at Faculty of Nursing, then develop an instructional plan for MCQs construction (one best answer format) to guide nursing educators. The study passed through exploratory-descriptive and methodological research designs at the Faculty of Nursing, Alexandria University, Egypt. Two samples were selected: First, 253 MCQs were selected from the different final exams (2017-2018) of the core twelve nursing subjects; Second, 21 academic nursing educators for evaluating of the suggested instructional plan. Both samples were chosen by convenience sampling technique. MCQs Assessment Form (MCQAF) was the first tool used to assess the construction quality of MCQs development and its items flaws. The second tool was MCQs' Instructional Plan Evaluation Sheet (MCQ IPES) which measured the content and face validity of the suggested instructional plan. The results revealed that $45.5 \%$ (115 MCQs) of the study sample contained ten item flaws. As regards the assessment of MCQs construction quality, evidently, the majority of nursing subject's exams has mean scores around a satisfactory level in MCQs quality construction. After submitting the developed plan to the expert group, almost the entire group found that the developed plan is accurate, with sound information, considered the useful and valued educational resource. Moreover, it has appropriate content in vocabulary, sentence structure, grammar, and concepts. Likewise, the experts reported that the developed plan is clear enough to be used by nursing educators and it is attractive and interesting self-reference tool. Conclusion \& recommendation: less than one half of the study MCQs has ten item flaws and almost all of them obtained satisfactory mean scores in MCQs quality construction. The developed instructional plan is a beginning and beneficial step for nursing educators and considered an instructional mean for MCQs construction guidance. Further studies are application of the developed plan among nursing educators and investigation of the awareness and compliance of nursing educators with the MCQs construction rules is needed.
\end{abstract}

Key Words: MCQs construction quality, Nursing, Educators, Item flaws and instructional plan

\section{INTRODUCTION}

Multiple-choice questions (MCQs) reflect an observable, constructive consequence of student's learning quality and knowledge retention experiences. MCQs tend to save the time and the effort, because it helps the teacher to asses a great number of students in an objective, reliable, and the valid manner in a short period. Moreover, it is easier in calculation electronically and its bank of questions can

\footnotetext{
*Correspondence: Azza Fathi Ibrahim; Email: azza_fathy2008@yahoo.com; Address: Nursing Education Departement, Faculity of Nursing, Alexandriea University, Alexandriea, Egypt.
} 
be constructed and utilized for prospect assessment. Evidently, MCQs are fitting to measure the higher cognitive skills such as critical thinking, problem-solving, decisionmaking and clinical judgment skills, mainly in medical and nursing education. Likewise, MCQs can measure cognitive, affective, and psychomotor domains of intended learning outcomes. Besides, MCQs are ideal styles of questions for easily comparing between students results and decreasing of evaluators' unfairness. Thus, it is a significant responsibility of the teachers to develop and write competent and efficient MCQs, particularly in higher nursing education settings. ${ }^{[1-4]}$ To be expert in developing high-quality MCQs, you should consider the subject' intended learning outcomes (ILOs), students abilities, and desires, ethical responsibilities, exam policies, tutoring strategies, and teaching content. Further, it is an obliged role of the nursing educator to ensure MCQs' validity and reliability which necessitate a grand sense of duty and inner moral conscientiousness. But, until now, many researchers found that it is a difficult mission and a challenge among nursing educators. ${ }^{[4-7]}$

While MCQs have a lot of evaluation benefits, there are a lot of difficulties in its writing; it is likely to be ambiguous for the respondents. Sometimes the students may fail to understand the data in the MCQ which lead to an incorrect answer. "The examinee' multiple guesses" is another limitation of the MCQs, in which the students tend to use guessing more than thinking. As well, if the students have some ideas about the question data, they can't gain any grades for this data if they choose the wrong option. Occasionally, some questions are focusing on a specific topic area and neglect other areas which may be considered by the students. Moreover, if the student is unable to know the right answer, he/she can select randomly which may be the right response by $25 \%$. Further, MCQs construction is a time-consuming job that requires an objective judgment $\&$ immense effort. ${ }^{[8-11]}$

There are two types of MCQs: true/false format in which the alternatives include many true options and the examinee should select all the right answers. While the other type is the single best answer type which is the most commonly used format and recommended measurement in applied \& health sciences evaluation. Single best answer MCQ is including 3-5 alternatives which ought to be plausible with only one best answer that should be selected by the examinee as a right answer. Therefore, the application of knowledge, creation, synthesis, and judgment experiences among nursing students can be easily measured by it than the true/false format. ${ }^{[6,10,11,16]}$

The main components of MCQ-one best answer are the stem, the lead-in, and 3-5 options. The stem of MCQ should design

Published by Sciedu Press to contain additional parts such as a vignette, a clinical case scenario, patient problem, a health graph, or a table. The stem ends with a lead-in question which should be a direct inquiry about how the students should respond. In healthcare sciences, and particularly in one best answer format, the lead-in question may be "What is the best-suggested nursing intervention?" or "What is the reason for the expected developed symptoms?" the lead-in is followed by the alternatives which should be harmonious, plausible with equal length as possible. The alternatives include one model answer which is called the right answer and the other alternatives are called the distracters. The previous structure is called the anatomy of MCQ. ${ }^{[6,8,10]}$

There are two types of MCQs' technical flaws that are frequently written by the educators: flaws with irrelevant difficulty (tricks) and flaws related to students' test-wiseness (clues). Nursing educators should avoid tricks and clues in MCQs test. Ambiguity, jargons and negative stems should be avoided. Additionally, the nurse educators have to avoid any grammatical errors in all components of the MCQs' structure or grammatical clues that link between the lead-in and the right answer. Repetitive word in MCQs' stem and in the right answer is a frequent guessing flaw and should be excluded. The options should be short, simple, and logical without any superfluous data comparing with the stem and the "lead-in" segments. ${ }^{[12-16]}$

Until now, MCQs for undergraduates nursing assessments, are frequently include item-writing flaws, or infringements to agree to item writing standardized guidelines. Thus, National League for Nursing (NLN) and Nursing's Core Competencies of Nurse Educators directed and mandated the nursing educators to employ different assessment approaches of the students which should be congruent with student's needs and evaluation transparency. ${ }^{[7,11,12]}$ The current research focuses on the investigation of MCQs construction quality of one best answer format and its common pitfalls. Then, an instructional plan about MCQs construction has been developed.

\subsection{The significance of the study}

Nursing educators need to strengthen their abilities to develop their MCQs test on a day-to-day basis. Faculty continuing education and academic staff training are essential processes to improve the academic programs, especially in a critical area such as students' evaluation. The World Health Organization (WHO) recommended that one of the most important Nurse Educator Core Competencies is to be accountable and responsible for the professional, effective and transparent assessment process. WHO emphasized that MCQs test is an essential instrument for the feasible and applicable measurement of student's higher cognitive skills. ${ }^{[6,17-19]}$ In 
general, the nurse educator should follow all rules of MCQs construction with a suitable plan.

An instructional plan about MCQs construction is a tutoring tool used by the nurse educator and students. It includes the components and the steps of establishing the teaching task that needed to reach the desired educational purpose. It considers the roadmap in which the educator can find all needed outline for the task. It saves the effort and time of the faculty. The instructional plan is a self-reference tool to guide the faculty and empower his/her self-awareness. ${ }^{[20-22]}$ MCQs are commonly employed tests configuration in healthcare sciences, but, they are still having multiple technical flaws. In nursing education, it necessitates investigating MCQs tests continuously and detecting any items flaws or any pitfalls. And consequently, instructional guidance and tools can be effective means among nursing faculties.

Therefore, the aims of the current study are to evaluate the construction quality of Multiple-Choice Questions (one best answer format) of nursing subject's exams and its common item flaws (2017-2018) at the faculty of nursing, Alexandria University. Then, develop of MCQs' instructional plan to guide nursing educators. To fulfill these aims, the following research theoretical framework was employed.

The context-input-process-output (CIPO) model is an essential systematic educational model of the development and executing the educator's tasks. It can be used in numerous areas within the educational spiral. ${ }^{[23]}$ This model utilizes an analytical framework through which the educational quality of the suggested plan can be assured, followed and assessed. It provides a systematic approach for the agenda of assessment, analysis, preparing, and development of the proposed MCQs instructional plan of the current study.

Specific Research Questions were developed for achieving the current study aims:

(1) What are the general features of MCQs (One Best Answer Format) in the twelve core nursing subject's exams 2017-2018 at the faculty of nursing, Alexandria University, Egypt?

(2) What are the common MCQs' items writing flaws (IWFs) - One Best Answer Format- in the twelve core nursing subject's exams 2017-2018 at the faculty of nursing, Alexandria University, Egypt?

(3) What are the assessment results of MCQs sample in the twelve core nursing subject's exams 2017-2018 at the faculty of nursing, Alexandria University, Egypt, in relation to question content \& formatting, writing the MCQ stem and writing of MCQ options?

(4) What is the expert group' evaluation feedback about the developed MCQs' instructional plan?

\section{MATERIALS AND METHOD}

\subsection{Study design}

Exploratory descriptive and methodological designs were carried out to achieve the study procedures.

\subsection{Sample and setting}

The data were collected at the four control rooms (exam papers' stores) in the Faculty of Nursing, Alexandria University, Egypt. After Dean legal permissions, the researcher photocopied the MCQs by mobile from the final exams (20172017) under restricted supervision of the control room's heads. The data were collected from two samples types: First, 253 MCQs were selected by convenience sampling technique from the twelve core nursing subjects' final exams (2017-2018) within the eight different academic levels in the nursing undergraduate program. Second, a convenient sample of 21 academic educators were selected from the faculty of nursing of Alexandria, Cairo, Zagazig, Damanhur and ain shams Universities, in Egypt and faculty of education from Cairo, Zagazig, and, Damanhur Universities, in Egypt. According to the epidemiological information statistical program "Bernard Rosner" 1999, ${ }^{[24]}$ the minimum sample size of 200 was estimated for MCQs and 18 for the jury committee. The inclusion criteria for MCQs selection was: to be One Best Answer Format, from the final exams of core nursing subjects, 2017-2018 (that already finished in the previous year) and the faculty dean consented to use those questions for the research purpose. The inclusion criteria for the jury committee was: from the faculty of nursing or faculty of education, have doctoral or post-doctoral academic degrees, used to develop MCQs tests in their academic work and accepted to participate in the study.

\subsection{Study tools}

Two tools were used for data collection:

Tool I: Multiple-Choice Question Assessment Form (MCQAF) which was developed by Coffman et al., in $2010^{[25]}$ to assess MCQs construction in quizzes. MCQAF consists of 21 standardized criteria for measuring the quality structure of the MCQs against a five-point Likert scale. The criteria represented as follow: two criteria for assessing the composition of question content, three criteria for question formatting suitability, six criteria for proper writing of MCQ stem, and ten criteria for the writing of the MCQ alternatives. The scale ranged from 1 (Not at all) to 5 (Exceptional). The scoring system ranged from 21 to 105 . If the MCQ scored in between $1>21$ it would denote poor construction. If the MCQ scored 
in between $21>42$ it would indicate that it needs improvement. If the question scored in between $42>63$, it would point to that it has marginal construction. If the question scored in between $63>84$, it would signify that the MCQ is acceptable. If the question got the score in between 85 to 105 , it would show exceptional MCQ construction. Based on each criterion of question content, formatting, writing of MCQ stem, and writing of the MCQ alternatives, the item flaws were estimated, determined and counted for each nursing subject exam and then calculated for all MCQs sample.

Tool II: MCQs' Instructional Plan Evaluation Sheet (IPES) which was developed by the researcher based on a thorough review of related literature ${ }^{[3,6,7,9,14,25]}$ and measured the content validity and face validity of the suggested instructional plan. It included two parts: First, statements about the judgments of the experts which concerning each step of the suggested plan which rated on a two-point rating scale: relevant and not relevant. Second, statements about the expert's views regarding the overall theme of the educational plan which in terms of clarity, feasibility, coverage, and attractiveness.

\subsection{Research procedure}

The present study was executed passing into four phases: context-input-process-output (CIPO) as following:

\subsubsection{Context phase}

A pilot study was applied for the study tools on thirty-three MCQs from the mentioned twelve exams and setting and they were excluded from the study sample. Necessary modifications were done. Study tools were checked for reliability by the Cronbach Alpha Coefficient Statistical Test which revealed acceptable level for both (tool I, $\alpha=0.78$ and for tool II = 0.71). Content validity was confirmed for both study tools by a jury of experts in community nursing, medicalsurgical nursing, nursing administration, and nursing education plus one professor from the faculty of education, to ensure content, face and criterion-related validity.

\subsubsection{Input phase}

Based on extensive literature review, and using of tool I, the researcher revise the MCQs of the twelve core nursing subjects' exams, namely: Fundamental of Nursing (20 MCQs), Medical-Surgical Nursing 1 (12 MCQs), MedicalSurgical Nursing 2 (35 MCQs), Critical Care Nursing (24 MCQs), Emergency Nursing (15 MCQs), Health Education (10 MCQs), Obstetric \& Gynecologic Nursing (20 MCQs), Pediatric Nursing (20 MCQs), Nursing Administration (24 MCQs), Psychiatric Nursing and Mental Health (50 MCQs), Geriatric Nursing (10 MCQs), Community Health Nursing (15 MCQs).

The assessment of the questions was against the criteria of Published by Sciedu Press tool I (Multiple-Choice Question Assessment Form). Each question was assessed for its construction quality of content; formatting, writing of MCQ stem, and writing of the question' alternatives. - each MCQ in each nursing exam took a mean score and standard deviation score on each criterion of tool I and then all means and standard deviations for all MCQs in a nursing exam collected and calculated for all criteria of tool I to provide one mean and one standard deviation. By this way, we can determine the grade of the exam in MCQs quality construction and to which extend it met the standardized rules in the assessment tool.

The process of assessment and revision was done two times, using the tool I to avoid any mistakes in items assessment and to overcome any calculation errors.

Common Item-Writing Flaws in MCQs were detected and reported for each exam and determined for all exams. Based on the tool I and related literature ${ }^{[6-8,14,18,22]}$ the technical item flaws for irrelevant difficulty (tricks) and flaws related to students' test-wiseness (clues) were assessed and detected. The researchers used nursing and medical education literature, which has an extensive evidence-base regard to the writing quality of MCQ items.

\subsubsection{Process phase (development of the instructional plan)}

Based on a thorough review of related literature ${ }^{[3,6,7,9,14,25,26]}$ and the input phase, the suggested instructional plan was prepared involving a broad aim for each step of MCQs construction, followed by some objectives which include strategies and active activities to meet the broad aim. Some of those activities attached with appendixes files (in a form of software icons) in which the nurse educator can find the explanation or detailed clarifications and examples to apply the required activities. Against each activity, there is the responsible person, timeline and evaluation that can guide the nurse educator to complete all elements of his/her training in writing high-quality MCQ.

The instructional plan was checked by experts in nursing education, medical education, psychiatric nursing, nursing administration and two professors in the faculty of education, before submitting to the jury committee (study sample 2) for evaluation. The experts ensured the content validity of the developed plan and necessary suggestions were done. They checked the plan content to decide if it matches the standardized criteria and process of MCQ construction, plus that the clarity and the feasibility of the activities were assessed. Also, they ensured to which extend the plan has a sound of evidence and theory that support its content. All adjustments were done. 


\subsubsection{Output phase}

A developed instructional plan on MCQs construction was given to the evaluation jury who used tool II to evaluate the plan for face validity, content validity, the clarity, feasibility, coverage, value, and attractiveness. All modifications were done.

\subsection{Data analysis}

Collected data was computerized, coded, analyzed and tabulated. Statistical Packages for the Social Sciences (SPSS) version 19.0 for Windows and Microsoft Excel Spread Sheet Package (Office 2010) were used for the results of the study. Descriptive statistics were done using numbers, percentage, arithmetic mean and standard deviation.

\subsection{Ethical considerations}

Official permission was taken from the Dean of Faculty of Nursing, Alexandria University, Egypt, for data collection from the four control rooms. The mentioned exams were photocopied by the mobile under restricted supervision of the control room's heads. Written informed consent was obtained from the jury sample after explaining the study pur- pose. Anonymity was reassured with the jury members by telling them to avoid putting their names on tool II. Confidentiality of the collected data and its analysis responses was ascertained.

\section{RESULTS}

Table 1 answers the question one of the present study and represents that the study sample of MCQs is 253 questions. $45.5 \%$ of them contained items flaws. $23.2 \%$ of the MCQs include clinical nursing problems. Each of Pediatric Nursing, Geriatric Nursing and Health Education exams consist of only 10 MCQs (3.9\%), while the Medical-Surgical Nursing II exam contains 35 MCQs (13.8\%). Psychiatric Nursing and Mental Health exam involve 50 MCQs (19.9\%). As regards the MCQs with the item's flaws (115 MCQs), because the Psychiatric Nursing and Mental Health exam involves a big number of MCQs, it has a major percent $8.3 \%$ of item flaws. It follows by Obstetric \& Gynecologic Nursing exam $4.7 \%$ of flaws. Whereas, Critical Care Nursing and Nursing Administration exams have equal percents $(4.3 \%)$ of item flaws.

Table 1. General features of MCQs in the core nursing subject's exams

\begin{tabular}{|c|c|c|c|c|c|c|c|c|}
\hline \multirow[t]{2}{*}{ Nursing Subject's Exams } & \multicolumn{2}{|c|}{ No. of MCQ } & \multicolumn{2}{|c|}{$\begin{array}{l}\text { No. of problems in } \\
\text { items }\end{array}$} & \multicolumn{2}{|c|}{$\begin{array}{l}\text { No. of MCQ } \\
\text { without flaws }\end{array}$} & \multicolumn{2}{|c|}{$\begin{array}{l}\text { No. of MCQ with } \\
\text { flaws }\end{array}$} \\
\hline & No & $\%$ & No & $\%$ & No & $\%$ & No & $\%$ \\
\hline Fundamental of Nursing & 20 & 7.9 & 4 & 1.6 & 11 & 4.3 & 9 & 3.6 \\
\hline Medical-Surgical Nursing I & 20 & 7.9 & 5 & 1.9 & 12 & 4.7 & 8 & 3.2 \\
\hline Medical-Surgical Nursing II & 35 & 13.8 & 12 & 4.7 & 20 & 7.9 & 15 & 5.9 \\
\hline Critical Care Nursing & 24 & 9.5 & 7 & 2.8 & 13 & 5.1 & 11 & 4.3 \\
\hline Emergency Nursing & 15 & 5.9 & 5 & 1.9 & 9 & 3.6 & 6 & 2.4 \\
\hline Health Education & 10 & 3.9 & 0 & 0.0 & 6 & 2.4 & 4 & 1.6 \\
\hline Obstetric \& Gynecologic Nursing & 20 & 7.9 & 0 & 0.0 & 8 & 3.2 & 12 & 4.7 \\
\hline Pediatric Nursing & 10 & 3.9 & 2 & 0.8 & 5 & 1.9 & 5 & 1.9 \\
\hline Nursing Administration & 24 & 9.6 & 2 & 0.8 & 13 & 5.1 & 11 & 4.3 \\
\hline Psychiatric Nursing and Mental Health & 50 & 19.9 & 19 & 7.5 & 29 & 11.5 & 21 & 8.3 \\
\hline Geriatric Nursing & 10 & 3.9 & 1 & 0.4 & 4 & 1.6 & 6 & 2.4 \\
\hline Community Health Nursing & 15 & 5.9 & 2 & 0.8 & 8 & 3.2 & 7 & 2.9 \\
\hline Total & 253 & 100 & 60 & 23.2 & 138 & 54.5 & 115 & 45.5 \\
\hline
\end{tabular}

Figure 1 illustrates the answer to question two of the current study and shows the rating of common MCQs' item writing flaws (IWFs) in the core nursing subjects exams (115 items). Ten item flaws are revealed as shown in the figure. The most apparent item flaw that observed in the MCQs of the nursing exams is using of "All-of-the-above" or "Noneof-the-above" or modifiers such as "usually" or "often" in the options $(31.3 \%)$, followed by "Measure simple recalling" (22.6\%), next is "Use of implausible destructors" (19.1\%) and subsequently is "Negatively worded stem" $(16.5 \%)$. The least frequent IWFs that observed are "Grammatical cues in the options" and "The correct answer length is more than or less than distracters" (8.7\%, and 6.1\%).

Tables 2-4 are clarifying the answer of the third question of the current study. As observed in Table 2, it illustrates the distribution of MCQs' items in the core nursing subject's exams according to the "MCQ content and formatting". All mean scores for all MCQs in nursing subjects' exams get mean scores $\leq 3.6$ which denote that the MCQs are above marginal 
level. Medical-surgical Nursing I, Pediatric Nursing, Nursing measure understanding \& application” the majority of MCQs Administration, and Community Health Nursing exams gain in nursing subjects exams have mean scores below 2.5 which satisfactory mean scores that are equal to 4 and less than 5. means that the MCQs need improvement. In general, the For almost all criteria of questions' content and formatting, majority of MCQs content and formatting get mean scores the MCQs have mean scores in between 3.5 to 4 (marginal above marginal \& around satisfactory scores.

and satisfactory scores). Except in the criteria of "Directed to

\section{Rating of MCQs item flaws}

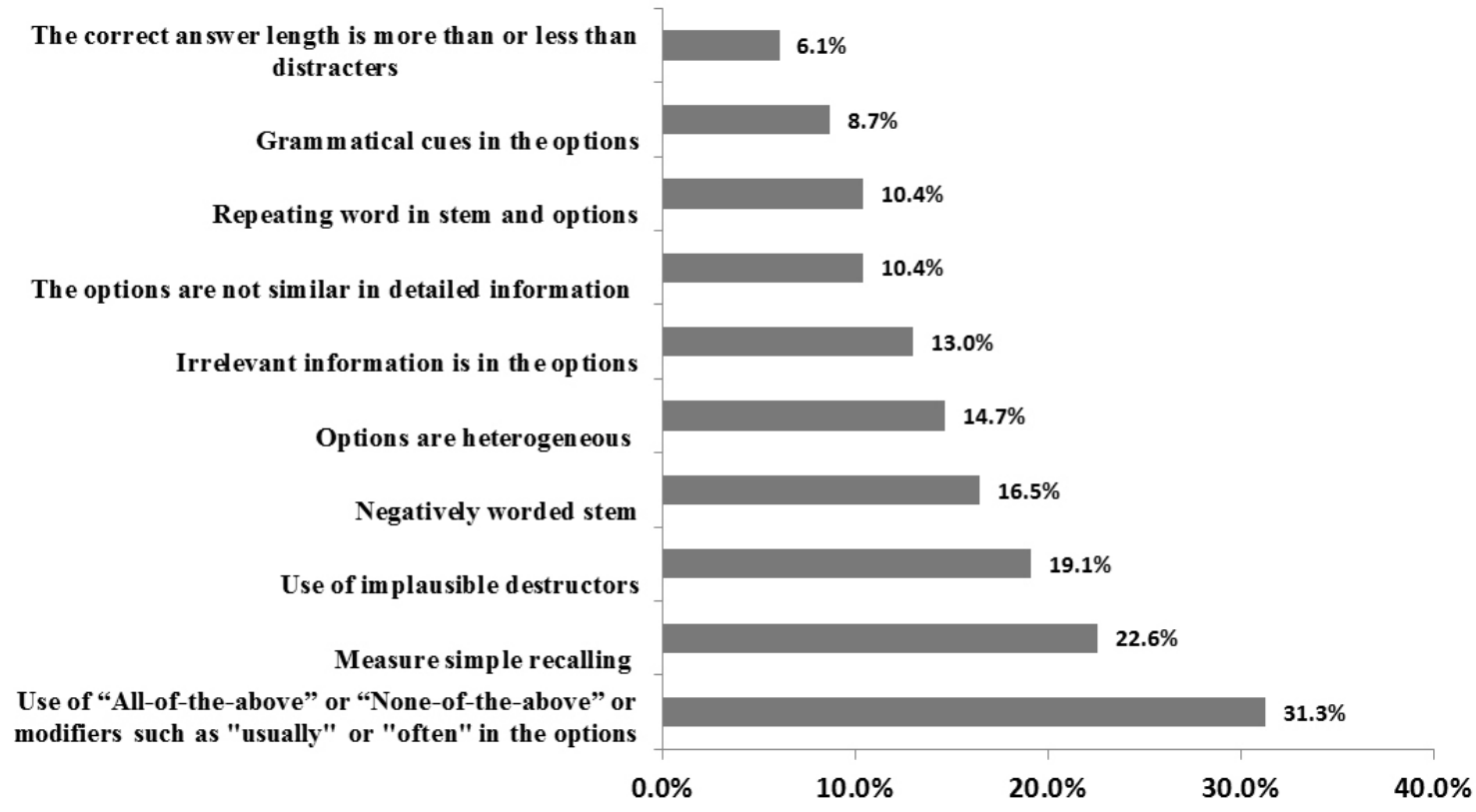

\section{MCQs item flaws (NB: One question may have 2 or more of flaws)}

Figure 1. Rating of common MCQs' items writing flaws (IWFs) in the core nursing subject's exams ( $N=115$ MCQs)

Table 2. Distribution of MCQs' items in the core nursing subject's exams according to the "MCQ content and formatting" as presented by mean and standards deviation $(\mathrm{N}=253 \mathrm{MCQs})$

\begin{tabular}{|c|c|c|c|c|c|c|c|c|c|c|c|c|}
\hline $\begin{array}{l}\text { The criteria of MCQ } \\
\text { assessment form } \\
\text { regarding the content }\end{array}$ & $\begin{array}{l}\text { Funda- } \\
\text { mental of } \\
\text { Nursing }\end{array}$ & $\begin{array}{l}\text { Medical- } \\
\text { surgical } \\
\text { Nursing I }\end{array}$ & $\begin{array}{l}\text { Medical- } \\
\text { Surgical } \\
\text { Nursing II }\end{array}$ & $\begin{array}{l}\text { Critical } \\
\text { Care } \\
\text { Nursing }\end{array}$ & $\begin{array}{l}\text { Emer- } \\
\text { gency } \\
\text { Nursing }\end{array}$ & $\begin{array}{l}\text { Health } \\
\text { Educa- } \\
\text { tion }\end{array}$ & $\begin{array}{l}\text { Obstetric } \\
\text { \& Gyne- } \\
\text { cologic } \\
\text { Nursing }\end{array}$ & $\begin{array}{l}\text { Pedia- } \\
\text { tric } \\
\text { Nursing }\end{array}$ & $\begin{array}{l}\text { Nursing } \\
\text { Adminis- } \\
\text { tration }\end{array}$ & $\begin{array}{l}\text { Psychiatric } \\
\text { Nursing \& } \\
\text { Mental } \\
\text { Health }\end{array}$ & $\begin{array}{l}\text { Geria- } \\
\text { tric Nur- } \\
\text { sing }\end{array}$ & $\begin{array}{l}\text { Commu- } \\
\text { nity } \\
\text { Health } \\
\text { Nursing }\end{array}$ \\
\hline \& formatting & $\begin{array}{l}\text { Mean } \pm \\
\text { SD }\end{array}$ & $\begin{array}{l}\text { Mean } \pm \\
\text { SD }\end{array}$ & $\begin{array}{l}\text { Mean } \pm \\
\text { SD }\end{array}$ & $\begin{array}{l}\text { Mean } \pm \\
\text { SD }\end{array}$ & $\begin{array}{l}\text { Mean } \pm \\
\text { SD }\end{array}$ & $\begin{array}{l}\text { Mean } \pm \\
\text { SD }\end{array}$ & $\begin{array}{l}\text { Mean } \pm \\
\text { SD }\end{array}$ & $\begin{array}{l}\text { Mean } \pm \\
\text { SD }\end{array}$ & $\begin{array}{l}\text { Mean } \pm \\
\text { SD }\end{array}$ & $\begin{array}{l}\text { Mean } \pm \\
\text { SD }\end{array}$ & $\begin{array}{l}\text { Mean } \pm \\
\text { SD }\end{array}$ & $\begin{array}{l}\text { Mean } \pm \\
\text { SD }\end{array}$ \\
\hline \multicolumn{13}{|l|}{ Question content: } \\
\hline $\begin{array}{l}\text { 1) Measure a single } \\
\text { educational objective }\end{array}$ & $4.4 \pm 0.80$ & $4.6 \pm 0.95$ & $4.3 \pm 0.80$ & $4.6 \pm 0.78$ & $4.1 \pm 0.75$ & $4.4 \pm 0.81$ & $4.1 \pm 0.78$ & $4.5 \pm 0.95$ & $4.8 \pm 0.77$ & $4.3 \pm 0.83$ & $4.3 \pm 0.80$ & $4.6 \pm 0.75$ \\
\hline $\begin{array}{l}\text { 2) Directed to measure } \\
\text { understanding \& } \\
\text { applications } \\
\text { Formatting: }\end{array}$ & $2.4 \pm 1.71$ & $3.4 \pm 0.98$ & $2.4 \pm 1.04$ & $2.3 \pm 1.76$ & $2.3 \pm 1.45$ & $2.4 \pm 1.16$ & $1.8 \pm 1.89$ & $2.4 \pm 1.15$ & $2.2 \pm 1.08$ & $2.3 \pm 0.81$ & $2.2 \pm 1.44$ & $3.2 \pm 1.11$ \\
\hline $\begin{array}{l}\text { 3) Options \& correct } \\
\text { answer are similar in } \\
\text { length. }\end{array}$ & $4.3 \pm 0.34$ & $4.2 \pm 0.75$ & $4.4 \pm 0.45$ & $4.4 \pm 0.76$ & $4.2 \pm 0.43$ & $4.3 \pm 0.23$ & $4.1 \pm 0.53$ & $4.4 \pm 0.43$ & $4.6 \pm 0.56$ & $4.2 \pm 0.23$ & $4.6 \pm 0.32$ & $4.3 \pm 0.25$ \\
\hline $\begin{array}{l}\text { 4) All options are } \\
\text { grammatically consis- } \\
\text { tent with the question } \\
\text { stem. }\end{array}$ & $3.9 \pm 0.88$ & $4.2 \pm 0.67$ & $3.4 \pm 1.23$ & $3.7 \pm 1.43$ & $3.3 \pm 1.23$ & $4.1 \pm 0.45$ & $3.2 \pm 1.67$ & $4.0 \pm 1.56$ & $3.8 \pm 1.12$ & $3.4 \pm 1.01$ & $3.2 \pm 1.23$ & $4.1 \pm 0.34$ \\
\hline $\begin{array}{l}\text { 5) The correct answer } \\
\text { includes the most } \\
\text { elements in common } \\
\text { with other options. }\end{array}$ & $4.1 \pm 0.94$ & $4.3 \pm 0.65$ & $4.5 \pm 0.47$ & $4.3 \pm 0.27$ & $4.1 \pm 0.80$ & $4.5 \pm 0.35$ & $4.3 \pm 1.35$ & $4.6 \pm 0.67$ & $4.4 \pm 0.45$ & $4.5 \pm 0.37$ & $4.4 \pm 0.48$ & $4.3 \pm 0.82$ \\
\hline Total & $3.8 \pm 0.93$ & $4.1 \pm 0.80$ & $3.8 \pm 0.79$ & $3.9 \pm 1.01$ & $3.6 \pm 0.85$ & $3.9 \pm 0.61$ & $3.5 \pm 1.02$ & $4.0 \pm 0.95$ & $4.0 \pm 0.80$ & $3.7 \pm 0.65$ & $3.7 \pm 0.85$ & $4.1 \pm 0.65$ \\
\hline
\end{tabular}


According to the results that present in Table 3 regarding the But Obstetric \& Gynecologic Nursing and Psychiatric Nursdistribution of MCQs' items in the core nursing subject's ing \& Mental Health exams have 3.9 mean scores which exams according to "writing the item stem", all of MCQs in denote very minimal difference. Generally, all exams of nursnursing subjects get around 4 mean scores which indicate ing subjects have satisfactory mean scores in writing MCQs that they have satisfactory scores in writing the MCQs' stem. stem.

Table 3. Distribution of MCQs' items in the core nursing subject's exams according to "writing the stem" as presented by mean and standards deviation ( $\mathrm{N}=253 \mathrm{MCQs})$

\begin{tabular}{|c|c|c|c|c|c|c|c|c|c|c|c|c|}
\hline $\begin{array}{l}\text { The criteria of MCQ } \\
\text { assessment form } \\
\text { regarding writing }\end{array}$ & $\begin{array}{l}\text { Fundame } \\
\text { ntal of } \\
\text { Nursing }\end{array}$ & $\begin{array}{l}\text { Medical- } \\
\text { surgical } \\
\text { Nursing I }\end{array}$ & $\begin{array}{l}\text { Medical- } \\
\text { Surgical } \\
\text { Nursing } \\
\text { II }\end{array}$ & $\begin{array}{l}\text { Critical } \\
\text { Care } \\
\text { Nursing }\end{array}$ & $\begin{array}{l}\text { Emer- } \\
\text { gency } \\
\text { Nursing }\end{array}$ & $\begin{array}{l}\text { Health } \\
\text { Educa- } \\
\text { tion }\end{array}$ & $\begin{array}{l}\text { Obstetric } \\
\text { \& Gyne- } \\
\text { cologic } \\
\text { Nursing }\end{array}$ & $\begin{array}{l}\text { Pediatric } \\
\text { Nursing }\end{array}$ & $\begin{array}{l}\text { Nursing } \\
\text { Adminis- } \\
\text { tration }\end{array}$ & $\begin{array}{l}\text { Psychiatric } \\
\text { Nursing \& } \\
\text { Mental } \\
\text { Health }\end{array}$ & $\begin{array}{l}\text { Geriatric } \\
\text { Nursing }\end{array}$ & $\begin{array}{l}\text { Com- } \\
\text { munity } \\
\text { Health } \\
\text { Nursing }\end{array}$ \\
\hline MCQ stem & $\begin{array}{l}\text { Mean } \pm \\
\text { SD }\end{array}$ & $\begin{array}{l}\text { Mean } \pm \\
\text { SD }\end{array}$ & $\begin{array}{l}\text { Mean } \pm \\
\text { SD } \\
\end{array}$ & $\begin{array}{l}\text { Mean } \pm \\
\text { SD } \\
\end{array}$ & $\begin{array}{l}\text { Mean } \pm \\
\text { SD }\end{array}$ & $\begin{array}{l}\text { Mean } \pm \\
\text { SD }\end{array}$ & $\begin{array}{l}\text { Mean } \pm \\
\text { SD }\end{array}$ & $\begin{array}{l}\text { Mean } \pm \\
\text { SD }\end{array}$ & $\begin{array}{l}\text { Mean } \pm \\
\text { SD }\end{array}$ & $\begin{array}{l}\text { Mean } \pm \\
\text { SD }\end{array}$ & $\begin{array}{l}\text { Mean } \pm \\
\text { SD }\end{array}$ & $\begin{array}{l}\text { Mean } \pm \\
\text { SD }\end{array}$ \\
\hline \multicolumn{13}{|l|}{ Writing the stem: } \\
\hline $\begin{array}{l}\text { 6) Clearly defines the } \\
\text { problem }\end{array}$ & $4.2 \pm 1.11$ & $4.3 \pm 0.55$ & $4.5 \pm 1.07$ & $4.2 \pm 1.29$ & $4.4 \pm 0.34$ & $4.2 \pm 0.78$ & $4.1 \pm 1.06$ & $4.2 \pm 0.35$ & $4.3 \pm 0.45$ & $4.2 \pm 0.37$ & $4.2 \pm 0.56$ & $4.2 \pm 0.89$ \\
\hline $\begin{array}{l}\text { 7) Includes as much } \\
\text { of the information }\end{array}$ & $4.6 \pm 0.48$ & $4.6 \pm 0.67$ & $4.3 \pm 1.23$ & $4.4 \pm 0.43$ & $4.2 \pm 0.73$ & $4.4 \pm 0.67$ & $4.1 \pm 0.69$ & $4.5 \pm 0.67$ & $4.4 \pm 0.45$ & $4.2 \pm 1.01$ & $4.1 \pm 0.78$ & $4.1 \pm 0.89$ \\
\hline $\begin{array}{l}\text { 8) No irrelevant } \\
\text { information is in the } \\
\text { question }\end{array}$ & $4.3 \pm 1.12$ & $4.2 \pm 0.45$ & $4.2 \pm 1.34$ & $4.1 \pm 0.81$ & $4.3 \pm 1.06$ & $4.2 \pm 1.23$ & $4.2 \pm 1.17$ & $4.1 \pm 1.08$ & $4.1 \pm 1.13$ & $4.3 \pm 0.35$ & $4.3 \pm 1.10$ & $3.8 \pm 1.14$ \\
\hline $\begin{array}{l}\text { 9) No grammatical } \\
\text { cues are in the } \\
\text { question }\end{array}$ & $3.8 \pm 1.34$ & $4.3 \pm 0.69$ & $4.1 \pm 1.04$ & $4.0 \pm 0.89$ & $3.9 \pm 1.24$ & $4.3 \pm 0.89$ & $3.7 \pm 1.04$ & $3.8 \pm 1.23$ & $3.8 \pm 1.43$ & $3.4 \pm 1.07$ & $4.1 \pm 0.45$ & $3.8 \pm 1.23$ \\
\hline $\begin{array}{l}\text { 10) No negative } \\
\text { statement has been } \\
\text { used }\end{array}$ & $3.3 \pm 1.09$ & $3.5 \pm 1.12$ & $3.8 \pm 1.45$ & $3.5 \pm 1.23$ & $3.9 \pm 0.94$ & $4.4 \pm 1.13$ & $3.4 \pm 1.45$ & $4.2 \pm 1.02$ & $4.1 \pm 0.89$ & $3.5 \pm 1.11$ & $3.7 \pm 1.32$ & $4.2 \pm 0.74$ \\
\hline $\begin{array}{l}\text { 11) Grammatically } \\
\text { consistent with the } \\
\text { options }\end{array}$ & $4.8 \pm 0.67$ & $4.3 \pm 0.84$ & $4.5 \pm 0.56$ & $4.5 \pm 0.89$ & $4.3 \pm 1.67$ & $4.1 \pm 0.68$ & $4.4 \pm 1.54$ & $4.1 \pm 1.12$ & $4.2 \pm 1.01$ & $4.3 \pm 1.02$ & $4.4 \pm 0.89$ & $4.1 \pm 1.14$ \\
\hline Total & $4.0 \pm 0.82$ & $4.2 \pm 0.72$ & $4.2 \pm 1.01$ & $4.1 \pm 0.92$ & $4.1 \pm 0.99$ & $4.2 \pm 0.89$ & $3.9 \pm 1.02$ & $4.1 \pm 0.91$ & $4.1 \pm 0.89$ & $3.9 \pm 0.82$ & $4.1 \pm 0.85$ & $4.0 \pm 1.00$ \\
\hline
\end{tabular}

Table 4. Distribution of MCQs' items in the core nursing subject's exams according to "Writing the Multiple-Choice Options" as presented by mean and standards deviation ( $\mathrm{N}=253 \mathrm{MCQs})$

\begin{tabular}{|c|c|c|c|c|c|c|c|c|c|c|c|c|}
\hline $\begin{array}{l}\text { The criteria of MCQ } \\
\text { assessment form } \\
\text { regarding Writing the } \\
\text { Multiple-Choice }\end{array}$ & $\begin{array}{l}\text { Funda- } \\
\text { mental of } \\
\text { Nursing }\end{array}$ & $\begin{array}{l}\text { Medical- } \\
\text { surgical } \\
\text { Nursing I }\end{array}$ & $\begin{array}{l}\text { Medical- } \\
\text { Surgical } \\
\text { Nursing II }\end{array}$ & $\begin{array}{l}\text { Critical } \\
\text { Care } \\
\text { Nursing }\end{array}$ & $\begin{array}{l}\text { Emer- } \\
\text { gency } \\
\text { Nursing }\end{array}$ & $\begin{array}{l}\text { Health } \\
\text { Educa- } \\
\text { tion }\end{array}$ & $\begin{array}{l}\text { Obstetric } \\
\text { \& Gyne- } \\
\text { cologic } \\
\text { Nursing }\end{array}$ & $\begin{array}{l}\text { Nursing } \\
\text { Pediatric } \\
\text { Nursing }\end{array}$ & $\begin{array}{l}\text { Nursing } \\
\text { Adminis- } \\
\text { tration }\end{array}$ & $\begin{array}{l}\text { Psychiatric } \\
\text { Nursing \& } \\
\text { Mental } \\
\text { Health }\end{array}$ & $\begin{array}{l}\text { Geriatric } \\
\text { Nursing }\end{array}$ & $\begin{array}{l}\text { Commu- } \\
\text { nity } \\
\text { Health } \\
\text { Nursing }\end{array}$ \\
\hline Options & $\begin{array}{l}\text { Mean } \pm \\
\text { SD }\end{array}$ & $\begin{array}{l}\text { Mean } \pm \\
\text { SD }\end{array}$ & $\begin{array}{l}\text { Mean } \pm \\
\text { SD }\end{array}$ & $\begin{array}{l}\text { Mean } \pm \\
\text { SD }\end{array}$ & $\begin{array}{l}\text { Mean } \pm \\
\text { SD }\end{array}$ & $\begin{array}{l}\text { Mean } \pm \\
\text { SD }\end{array}$ & $\begin{array}{l}\text { Mean } \pm \\
\text { SD }\end{array}$ & $\begin{array}{l}\text { Mean } \pm \\
\text { SD }\end{array}$ & $\begin{array}{l}\text { Mean } \pm \\
\text { SD }\end{array}$ & $\begin{array}{l}\text { Mean } \pm \\
\text { SD }\end{array}$ & $\begin{array}{l}\text { Mean } \pm \\
\text { SD }\end{array}$ & $\begin{array}{l}\text { Mean } \pm \\
\text { SD }\end{array}$ \\
\hline \multicolumn{13}{|l|}{$\begin{array}{l}\text { Writing the Multiple- } \\
\text { Choice Options: }\end{array}$} \\
\hline $\begin{array}{l}\text { 12) All distractors are } \\
\text { plausible alternatives }\end{array}$ & $3.4 \pm 1.04$ & $3.2 \pm 1.66$ & $3.3 \pm 1.03$ & $3.4 \pm 1.53$ & $3.1 \pm 1.67$ & $3.2 \pm 0.21$ & $3.4 \pm 1.67$ & $3.1 \pm 1.76$ & $3.4 \pm 1.36$ & $3.3 \pm 0.78$ & $3.2 \pm 1.45$ & $3.3 \pm 1.34$ \\
\hline $\begin{array}{l}\text { 14) All options are of the } \\
\text { same complexity of } \\
\text { terms. }\end{array}$ & $3.1 \pm 1.45$ & $3.3 \pm 1.23$ & $3.4 \pm 0.89$ & $3.4 \pm 1.11$ & $3.3 \pm 1.31$ & $3.3 \pm 1.21$ & $3.2 \pm 1.17$ & $3.1 \pm 1.51$ & $3.4 \pm 1.21$ & $3.3 \pm 1.32$ & $3.2 \pm 0.79$ & $3.3 \pm 1.41$ \\
\hline $\begin{array}{l}\text { 15) No two options have } \\
\text { the same meaning. }\end{array}$ & $4.3 \pm 0.83$ & $4.2 \pm 0.89$ & $4.4 \pm 0.93$ & $4.3 \pm 1.03$ & $4.3 \pm 0.97$ & $4.1 \pm 1.11$ & $4.3 \pm 1.15$ & $4.00 \pm 1.18$ & $4.4 \pm 0.73$ & $4.2 \pm 1.06$ & $4.3 \pm 1.03$ & $3.9 \pm 1.56$ \\
\hline $\begin{array}{l}\text { 16) The answer has been } \\
\text { randomly assigned to } \\
\text { one of the positions. }\end{array}$ & $4.2 \pm 1.06$ & $3.8 \pm 1.18$ & $4.2 \pm 0.89$ & $4.1 \pm 1.11$ & $4.0 \pm 0.83$ & $4.3 \pm 1.03$ & $3.9 \pm 1.44$ & $4.00 \pm 1.15$ & $4.3 \pm 0.79$ & $4.1 \pm 1.02$ & $3.8 \pm 1.11$ & $4.3 \pm 1.18$ \\
\hline $\begin{array}{l}\text { 17) The distractors are } \\
\text { important, detailed, with } \\
\text { technical sounding. }\end{array}$ & $3.8 \pm 0.95$ & $4.1 \pm 1.07$ & $4.00 \pm 1.11$ & $3.9 \pm 1.28$ & $4.2 \pm 0.93$ & $4.3 \pm 1.03$ & $3.8 \pm 1.08$ & $3.7 \pm 1.14$ & $4.1 \pm 1.11$ & $3.7 \pm 1.43$ & $4.1 \pm 1.09$ & $4.0 \pm 0.79$ \\
\hline $\begin{array}{l}\text { 18) The correct answer } \\
\text { has been described in } \\
\text { more detail similar to } \\
\text { distractors. }\end{array}$ & $4.00 \pm 0.87$ & $3.8 \pm 1.12$ & $4.2 \pm 0.67$ & $3.9 \pm 1.04$ & $3.8 \pm 1.25$ & $3.6 \pm 1.11$ & $4.0 \pm 0.89$ & $4.1 \pm 0.87$ & $3.9 \pm 1.04$ & $3.8 \pm 0.89$ & $4.0 \pm 1.01$ & $3.6 \pm 0.98$ \\
\hline $\begin{array}{l}\text { 19) The length of the } \\
\text { correct answer has been } \\
\text { varied. }\end{array}$ & $4.6 \pm 0.75$ & $4.0 \pm 0.67$ & $3.8 \pm 1.09$ & $4.5 \pm 0.79$ & $4.4 \pm 0.89$ & $4.0 \pm 0.94$ & $4.3 \pm 0.95$ & $4.2 \pm 0.67$ & $4.5 \pm 1.06$ & $4.0 \pm 1.11$ & $3.8 \pm 1.21$ & $4.1 \pm 0.78$ \\
\hline $\begin{array}{l}\text { 20) All options are } \\
\text { similar but one correct is } \\
\text { clearly the best answer. }\end{array}$ & $2.3 \pm 1.45$ & $2.2 \pm 1.28$ & $3.00 \pm 1.65$ & $2.8 \pm 1.13$ & $2.2 \pm 1.22$ & $3.2 \pm 1.05$ & $2.2 \pm 1.95$ & $2.8 \pm 1.76$ & $2.4 \pm 1.95$ & $3.1 \pm 1.89$ & $2.3 \pm 1.79$ & $2.5 \pm 1.67$ \\
\hline $\begin{array}{l}\text { 21) No use of } \\
\text { "All-of-the-above" or } \\
\text { "None-of-the-above" or } \\
\text { modifiers such as } \\
\text { "usually" or "often" in } \\
\text { the options. }\end{array}$ & $4.1 \pm 0.69$ & $4.3 \pm 0.89$ & $4.5 \pm 0.67$ & $4.4 \pm 0.83$ & $4.2 \pm 0.78$ & $4.5 \pm 0.92$ & $3.8 \pm 1.04$ & $4.5 \pm 0.73$ & $4.4 \pm 0.94$ & $4.5 \pm 0.84$ & $4.8 \pm 0.81$ & $4.6 \pm 0.95$ \\
\hline Total & $3.7 \pm 1.09$ & $3.6 \pm 1.19$ & $3.8 \pm 1.02$ & $3.7 \pm 1.09$ & $3.6 \pm 1.13$ & $3.7 \pm 0.98$ & $3.4 \pm 1.24$ & $3.7 \pm 1.19$ & $3.8 \pm 1.14$ & $3.7 \pm 1.12$ & $3.6 \pm 1.11$ & $3.7 \pm 1.15$ \\
\hline
\end{tabular}


Concerning Table 4, that describes the distribution of MCQs' items in the core nursing subject's exams according to "Writing the Multiple-Choice Options". Obviously, the mean scores for all the MCQs are ranged in between 3.4 to 3.8 which signify that all the questions have above marginal scores in the construction of the MCQs' options. Obstetric \& Gynecologic Nursing exam has the least mean score = 3.4 while, Medical-Surgical Nursing II and Nursing administration exams obtain the highest mean score $=3.8$. In the criteria of "All options are similar but one correct is clearly the best answer", almost MCQs in all nursing exams have mean scores below 3 which indicate that the MCQs sample needs improvement is this criterion.

Figure 2 provides a summary of the overall mean scores that reveal in the results of MCQs construction assessment among the core nursing subjects exams. Evidently, the majority of the nursing subjects exams ( 7 exams have 4 or 3.9 mean scores) have mean scores around a satisfactory level in the development of MCQs. The remaining nursing subjects exams have mean scores around 3.7, 3.8, also, consider near satisfactory scores in MCQs construction.

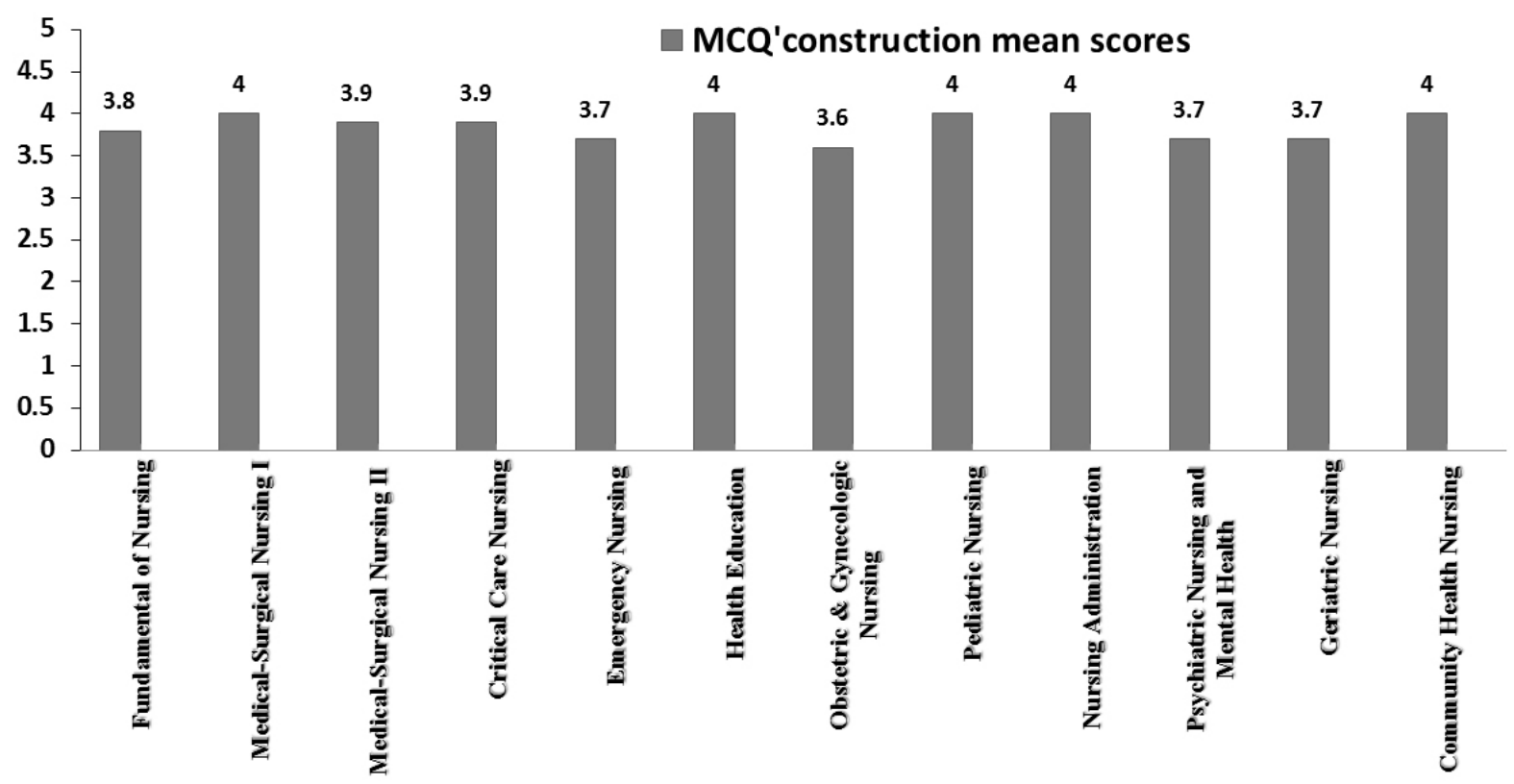

Figure 2. Distribution of the core nursing subject's exams according to MCQs' construction mean scores in the assessment form ( $\mathrm{N}=253 \mathrm{MCQs})$

Pertaining to the expert's feedback about the developed instructional plan, Table 5 illustrates this point. In general, the expert group has a positive perception of the developed instructional plan, because they give constructive responses when using tool II. All experts (100\%) found that the plan includes accurate and sound information and it is a useful and valued educational resource. Moreover, most of the expert group (95.2\%) reported that the developed plan represents appropriate content in vocabulary, sentence structure, grammar, and concepts. As well as, it is clear enough to be used by nursing educators. Further, it is an attractive and interesting self-reference tool. The majority of them $(90.5 \%)$ mentioned that the plan is understandable with update information and it is feasible and applicable to be used by nurse educators. However, limited percent $(33.3 \%)$ of the experts clarified that the developed plan is not easy to be used for MCQs construc- tion. Additionally, $28.6 \%$ and $23.8 \%$ of them perceived that the plan is not meet the expectations of the nursing educators and not organized in the fluency of evident information. Concerning the expert opinions as regards the week points of the developed instructional plan, minimal percents of them $(9.5 \%$ and $14.3 \%$ ) commented that it is crowded, need organization, difficult to be followed and need revising. Conversely, for the strong points of the developed plan, great percents $(85.7 \%$, $71.4 \%, 57.1 \%$, and $76.2 \%$ ) of the experts declared that it is clear, useful, self-reference tool and complete. Finally, the experts suggested some points that help in improvement of the developed plan, more than one half $(57.1 \%$ and $52.4 \%)$ of the experts affirmed that it is better to decrease details of the plan, use pictures and graphics to attract the reader's attention and add some arrows for directions and clarifying the contents of the column in the plan. 
Table 5. MCQs' Instructional Plan evaluation as perceived by the expert's group

\begin{tabular}{|c|c|c|c|c|}
\hline \multirow{3}{*}{ Evaluation criteria for MCQs Instructional Plan } & \multicolumn{4}{|c|}{ Experts Group (N = 21) } \\
\hline & \multicolumn{2}{|c|}{ Relevant } & \multicolumn{2}{|c|}{ Irrelevant } \\
\hline & No. & $\%$ & No. & $\%$ \\
\hline 1) The plan content is suitable for the purpose of the study & 17 & 80.9 & 4 & 19.0 \\
\hline 2) The plan content is suitable for nursing educators' work & 16 & 76.2 & 5 & 23.8 \\
\hline 3) The instructional plan is easy to be used for MCQs construction & 14 & 66.7 & 7 & 33.3 \\
\hline 4) The instructional plan is understandable with update information & 19 & 90.5 & 2 & 9.5 \\
\hline 5) The instructional plan represents appropriate content in vocabulary, sentence structure, grammar and concepts. & 20 & 95.2 & 1 & 4.8 \\
\hline 6) The instructional plan includes accurate and sound information & 21 & 100 & 0 & 0.00 \\
\hline 7) The instructional plan will meet the expectations of the nursing educators & 15 & 71.4 & 6 & 28.6 \\
\hline 8) The instructional plan is organized in the fluency of evident information & 16 & 76.2 & 5 & 23.8 \\
\hline 9) The instructional plan is clear enough to be used by nursing educators & 20 & 95.2 & 1 & 4.8 \\
\hline 10) The instructional plan is attractive and interesting self-reference tool & 20 & 95.2 & 1 & 4.8 \\
\hline 11) The instructional plan is feasible and applicable to be used by nurse educators & 19 & 90.5 & 2 & 9.5 \\
\hline 12) The instructional plan covers all needed information about MCQs construction. & 15 & 71.4 & 3 & 14.3 \\
\hline 13) The instructional plan will meet the individual differences & 18 & 85.7 & 3 & 14.3 \\
\hline 14) The instructional plan is useful and valued educational resource & 21 & 100 & 0 & 0.00 \\
\hline \multirow{2}{*}{ Expert's opinions about the instructional plan } & \multicolumn{4}{|c|}{ Experts Group (N = 21) } \\
\hline & No. & & $\%$ & \\
\hline \multicolumn{5}{|l|}{ Weak points of the instructional plan: } \\
\hline 1) Crowded & 2 & & 9.5 & \\
\hline 2) Need organization & 3 & & 14.3 & \\
\hline 3) Difficult to follow & 3 & & 14.3 & \\
\hline 4) Need revising & 2 & & 9.5 & \\
\hline 5) None & 12 & & 57.1 & \\
\hline \multicolumn{5}{|l|}{ Strong points of the instructional plan: } \\
\hline 6) Clear & 18 & & 85.7 & \\
\hline 7) Useful & 15 & & 71.4 & \\
\hline 8) Self-reference tool & 12 & & 57.1 & \\
\hline 9) Complete & 16 & & 76.2 & \\
\hline 10) None & 3 & & 14.3 & \\
\hline \multicolumn{5}{|l|}{ Suggestions to improve the instructional plan: } \\
\hline 11) Decrease details of the plan & 12 & & 57.1 & \\
\hline 12) Use pictures and graphics & 11 & & 52.4 & \\
\hline 13) Add more examples of MCQs in nursing fields. & 6 & & 28.6 & \\
\hline 14) Develop a step for each nursing specialty in examples of MCQs construction & 7 & & 33.3 & \\
\hline 15) Add arrows for directions and clarifying the contents of the column in the plan. & 12 & & 57.1 & \\
\hline 16) None & 4 & & 19.0 & \\
\hline
\end{tabular}

\section{Discussion}

MCQs assessment was discussed in several portions of evidence and included extremely parallel information. ${ }^{[1,3,4,12,14]}$ Evaluation of the effectiveness of MCQs development in this work is depending on the assessment criteria found in the educational measurement literature. ${ }^{[3,6,7,9,14,25,26]}$ While there are a lot of references that guide writing of MCQs, there are a little practical foundation and research studies about the development of competent MCQ test. Also, there are minimal investigations about MCQs construction quality and its violation of this construction. Nowadays, the development of instructional tools to direct the academics in designing the MCQs test, particularly in nursing education, is necessitate educational target. ${ }^{[3-5]}$

In the current study results and in relation to the general fea- tures of the study sample, the next data provides an answer to the first question of the study. Less than one half (45.5\%) of MCQs in the nursing subject's exams contain writing flaws which indicated that there is an acceptable rate of flaws in writing MCQs among nursing academia in Alexandria, Egypt. This finding is congruent with Tarannt et.al, in 2006 who confirmed that there was a tolerable flaw rate (46.2\%) in writing MCQs among nursing educators. As well as, in 2016, Omar et al., discovered that 39\% flawed items in 49 violations of the item-writing guidelines among undergraduate MCQs tests. ${ }^{[27,28]}$ Contradictory, with this line, Cayo et. al., in 2013 found that there was high flaws rate (85\%) in writing online MCQs. Furthermore, in 2017, Hijji found that 91.8\% of MCQs which under investigation experienced one or more item-writing flaws. ${ }^{[26,29]}$ MCQs items flaws affect negatively on nursing student's evaluation which should be 
managed and minimized.

As well, in the present study, MCQs' stems include only $23.2 \%$ of clinical problems or hypothetical nursing situation. The current result is incompatible with Case and Swanson in 2001. They highlighted that MCQs stem in basic and clinical health sciences exams such as nursing and medicine should contain an application of knowledge in several clinical and practical situations. Presence of clinical cases and circumstances in the MCQs stem, allows the students to think, judge, conclude, manage and apply the information as higher cognitive skills. ${ }^{[6,7]}$ Relating to the common MCQs' items writing flaws (IWFs), only $115 \mathrm{MCQs}$ have ten item flaws. The most apparent item flaw (31.3\%) was "using of All-of-the-above" or "None-of-the-above" or modifiers such as "usually" or "often". This flaw facilitated the student's test-wiseness. Thus, it should be avoided. Corresponding to the current finding, Tarrant and Ware in 2008 mentioned that many educators in health sciences tend to write modifiers (e.g. always, never) or using of "all of the above", which are confusing and forbidden to be used in MCQs exams. Among some students, these flaws may help them in guessing the right response and for other students, they may disturb their thinking. ${ }^{[26,30]}$ Furthermore, and in the same line, DiBattista et al., in 2014 concluded that while "none of the above" is used as a right response, the students with low knowledge recognize that the item seems to have extra discriminatory influence that is truly the case. So, the instructive investigators proposed that "none of the above" should be excluded from all health sciences MCQs tests. ${ }^{[30,31]}$ Nurse educators have to recognize the effects of this flaw on students and on the assessment results. It can be hurt achiever students more than failed ones.

The next MCQs' item flaw in the recent study is "Measure simple recalling" which represents by $22.6 \%$ among flawed MCQs. Plentiful examiners wrote this flaw in the MCQs test, but, if the MCQ included it, the test will be ineffective. Besides, and worldwide, this flaw is contradicting with the targets of nursing programs which is equipping nursing students with higher cognitive skills. Congruent with this result, Elhassan et al., in 2011 spotlighted that MCQs should assess the higher level of thinking which represent student's competency, especially in the best-answer type. When assessing the higher level of students' cognitive skills, you can discriminate between the students and this discrimination indicates your success in developing good MCQs items. According to Miller's Pyramid of clinical competence, MCQs should test student's analysis, application, synthesizing, evaluation and creation of knowledge, not simply knowledge. ${ }^{[32-34]}$ In the clinical field such as nursing, it is prohibited to assess simple recall of facts, because the nurses are in a vital job.
The subsequently revealed MCQs' flaw in the present study is "Use of implausible destructors" which represents $19.1 \%$ of the flawed MCQs. Several references reported that there are a lot of educators in higher education design implausible destructors which considered a violation of the MCQs construction guideline. Fitting to this point, Mukherjee and Lahiri in 2015 discussed that a crucial feature of MCQs' distractors, is to be reasonable and plausible answers, like the keyed response. Careful designing for plausible distractors is very important to increase MCQs quality. ${ }^{[34,35]}$

Afterward, the flaw detected in the study sample is "Negatively worded stem" which represents $16.5 \%$ of the MCQs. Negatively worded stem push the achiever's students to select the wrong answer, even, the educator emphasizes and highlights it (for example, except, not). Harmonizing with this line, Chiavaroli, in 2017 mentioned that using a negatively worded stem in MCQs test is completely prohibited because a considerable percentage of students answer this MCQs as if it was positively worded. The constant employ of negative phrased MCQs in high-stakes tests of clinical fields create an apparent risk and violation of the validity and rules of students evaluation. ${ }^{[17,36]}$ Flawed MCQs hinder the credibility and meaningful explanation of the exam results and have unconstructively influence on student pass rates.

The second question in the present study is answered by the following result concerning MCQs assessment. For MCQs item content and formatting, the majority of MCQs study sample get above marginal and satisfactory mean scores. In the same line with this result, Cayo et al., in 2013 discussed that the acceptable MCQ's content depends on determining of a specific objective to be measured and tailoring the relevant content in the alternatives of the MCQ item. Similarly, Brame in 2013 described that the acceptable MCQs content should present an exact problem which is pertinent to the course objectives. Stem and options content with proper formatting have to be linked and matched as possible. ${ }^{[26,37]}$ In the current study, there is only one criterion "measure understanding \& application" in MCQs content assessment have below 2.5 mean scores among nearly all of MCQs sample. Almost MCQs in this point need improvement. Harmoniously, with this result, Gajjar et al., in 2014 emphasized that internationally; the majority of academics tend to write MCQs content to measure lower cognitive level which at the recall level of Bloom's Taxonomy. ${ }^{[4,26]}$ It is a big challenge among nursing academics to design MCQs content and options for measuring student's higher cognitive capabilities.

Pertaining to, MCQs's stem assessment, approximately all of MCQs sample get above 4 mean scores which indicate the satisfactory level in writing the MCQs' stem. Matching 
with this line, Jovanovska in 2018, documented that the fitting MCQs item should include a well-prepared stem which designed with a sound relevant clinical problem. Moreover, Brame in 2013, recommended that the appropriate MCQs stems have to attract the students to spend a cognitive load of analysis to reach a solution of a stem' problem. ${ }^{[37,38]} \mathrm{Con}$ trasting with these views, Cayo et al., in 2013 and Jovanovska in 2018 clarified that there are many teachers still incompetent to develop acceptable MCQs' stem which is very dangerous on student's evaluation. Unsatisfactory MCQs stem may permit the students to estimate the right answer and reduce the validity and reliability of the test. ${ }^{[26,38]}$

Relating to the current result about assessing the MCQ's alternatives, the majority of the study sample gets approximately, above marginal scores in developing of the MCQs' options. Further and particularly, in the criteria of "All options are similar but one correct is clearly the best answer", almost MCQs have mean scores below 3 which indicate that the majority of them need revision and improvement. Such revision should be in arranging homogenous MCQs options and design the answer like them as possible. In the line with this finding, Collins in 2006, Brame in 2013 and Hijji in 2017 mentioned that although there are a lot of researches on the guideline for successful MCQs writing, there are many breaches of these rules, particularly in options development. These violations are frequently observed in the field of medical and health education. The main obstacle of MCQs development is the constructing of reasonable and similar alternatives that include one best keyed-response. ${ }^{[29,37]}$ However, and according to Schuwirth, and Pearce in 2014, the Australian Medical Assessment Collaboration (AMAC), the American National Board of Medical Examiners Manual and Assessment Policy - Medicine, Nursing and Health Sciences documented that implausible distractors, trivial or nonsensical distractors should not be included in undergraduate MCQs tests. The educators must put all options in a similar category of content and similar to the right response in length, difficulty, and grammar, as possible. ${ }^{[39,40]}$ Unfortunately, the academics still need a sort of regular and frequent guidance about the construction of MCQs' plausible distractors.

For the answer to question three in the current study, the majority mean scores of MCQs assessment are satisfactory. It is a good sign of the MCQs development in the Faculty of Nursing, Alexandria University, Egypt. Matching, with this finding, Abdulghani et al., in 2017 discussed that the enhancement for the excellence construction of the MCQs may support the soundness of the test among faculties. Further, better attainment of the student's evaluation and the comparison of their results become available. But, unlike to such result, Baig et al., in 2014 found that there is necessitate for revising the quality of the MCQs test content by the program team because it is frequently not credible. ${ }^{[41,42]}$ Parallel to this study finding, recently, in a research study in Egypt by Nassar in 2017 who reported that the high-quality MCQs is needed for undergraduate student's assessment in healthcare sciences. MCQs tests should be assessed and adjusting of any pitfalls or flaws. ${ }^{[26,43]}$ Even the results of the recent study are positive and denote accepted level of MCQs development of the study sample, training programs, and instructional tools still required for nursing academia.

As regarding the feedback and evaluation of the expert group concerning the developed instructional plan, almost all of the experts' perceptions are positive. They reported that the developed plan is suitable as a reminder for nursing educators when developing the MCQs test. Parallel to the current result, Hui Xu, in 2016, discussed that nursing education should find all strategies to help nursing educators in their missions, especially in students evaluation. They should look for guidance or manuals to help themselves and consequently their students. Conversely, academic development is usually limited and requires considerable economic funds and advanced technology, particularly in developed countries. In the same time, many educators neglect to follow any new updates and guidance for self-directed learning. ${ }^{[44]}$ Therefore, in Egypt, developing innovative educational interventions among nursing educators is a necessary step of a total educational plan for the education system.

Around all of the experts found that the developed plan includes accurate and sound information. It is a useful and valued educational resource. It represents appropriate content in vocabulary, sentence structure, grammar, and concepts. Moreover, they reported that the developed plan is clear enough to be used by nursing educators and it is attractive and interesting self learning-reference tool. Likewise to the present result, the World Health Organization (WHO) in 2016 developed a booklet about the core competencies of nurse educators. The authors stressed that nurse educators are the entrance keepers of the profession because they have the crucial task to make sure that the students are competent to apply the art and science of nursing. But, also, they are responsible for their continuous training and updating of their knowledge and skills. WHO presented the booklet for the educators after the content revision by nursing educators' expertise; they assessed it for its relevancy, clarity, feasibility, completeness, and comprehensiveness. Besides, the authors ensured that the booklet is investigated by strategically coordinated efforts to ascertain its validity and reliability. The authors concluded that if the booklet content was adopted and adapted well, the faculties would be equipped with high-quality competences in teaching. ${ }^{[44,45]}$ 
Continuing professional development is anticipated for all nursing educators all over the world because they have a lot of academic roles in and outside the educational setting. Instructional materials have important functions among nursing academics, particularly in a challenging aspect such as students' evaluation.

\section{Conclusion}

In nursing education, it is extensively recommended to develop instructional means for nursing educators. So, the developed plan for MCQs construction is a beneficial step for improving nursing students' evaluation process and nursing education paradigm as a whole. In the current study, the results revealed that $45.5 \%$ (115 MCQs) of the study sample contains ten items of flaws. Evidently, the majority of the nursing subject's exams have mean scores around a satisfactory level in the development of MCQs. After submission of the developed plan for MCQs construction to the expert group, they found that the plan is accurate and with sound information, useful and valued educational resource and has appropriate content in vocabulary, sentence structure, grammar, and concepts. Moreover, they reported that the developed plan is clear enough to be used by nursing educators and it is attractive and interesting self-reference tool.

\section{Recommendations and further studies}

The nurse educators are the entrance keepers of the profession. So, continuous assessment of nursing student's evalua- tion tests is necessary and further investigation of common flaws in the exams is an obligation. More developments of instructional means and curricular content guidance for nursing educators are recommended. The present study provided a view for further studies such as:

(a) Using the developed plan among nursing educators to ensure its feasibility and effectiveness among them.

(b) Investigation of the awareness and compliance of nursing educators with the MCQs construction rules is needed.

(c) Development of further e-instructional tools to guide nursing educators in students teaching and learning process.

(d) A study about the relationship between MCQs common item flaws and nursing student's scores and success rate.

(e) Assessment of nurse educator's self-efficacy, satisfaction, and attitude regarding professional development in the faculty of nursing, University of Alexandria.

(f) Replication of the current study using other instruments.

\section{ACKNOWLEDGEMENTS}

The author is thankful to the Deanship of the Faculty of Nursing, Alexandria University, Egypt, for the support of this research project.

\section{CONFLiCTS OF INTEREST Disclosure}

The authors declare that there is no conflict of interest.

\section{REFERENCES}

[1] Khan MZ, Aljarallah BM. Evaluation of Modified Essay Questions (MEQ) and Multiple Choice Questions (MCQ) as a tool for Assessing the Cognitive Skills of Undergraduate Medical Students. International Journal of Health Sciences, Qassim University. 2011; 5(1): 4-50.

[2] Edward JP, Peter GD. Assessment of higher order cognitive skills in undergraduate education: modified essay or multiple choice questions? BMC Medical Education. 2007.

[3] Reichert TG. Assessing The Use of High Quality Multiple Choice Exam Questions in Undergraduate Nursing Education: Are Educators Making the Grade? Scholarly Project Submitted in Partial Fulfillment of the Requirements for the Degree of Masters in Nursing Education, Catherine University. 2011; 4-43.

[4] Gajjar S, Sharma R, Kumar P, et al. Item and Test Analysis to Identify Quality Multiple Choice Questions (MCQs) from an Assessment of Medical Students of Ahmedabad, Gujarat. Indian J Community Med. 2014; 39(1): 17-20. PMid:24696535 https: //doi.org/10.4103/0970-0218.126347

[5] D'Sa JL, Dionaldo ML. Analysis of Multiple Choice Questions: Item Difficulty, Discrimination Index and Distractor Efficiency. International journal of Nursing Education. 2017; 9(3): 109-114. https://doi.org/10.5958/0974-9357.2017.00079.4
[6] Case SM, Swanson DB. Constructing Written Test Questions for the Basic and Clinical Sciences. 3rd ed. Philadelphia: National Board of Medical Examiners; 2001; 13-55.

[7] Mc Coubrie P. Improving the fairness of multiple-choice questions: a literature review. Medical Teacher. 2004; 26: 709-712. PMid:15763874 https://doi.org/10.1080/01421590400013 495

[8] Redmond SP, Hartigan-Rogers JA, Cobbett S. High time for a change: psychometric analysis of multiple-choice questions in nursing. International Journal of Nursing Education Scholarship. 2012; 9(1). PMid:23192053 https://doi .org/10.1515/1548-923X.2487

[9] Monash Assessment Vision. 2016. Available from: http://intr anet.monash.edu.au/learningandteaching/enhancingte aching/assessmentstrategies/assessment-vision.html

[10] Downing S. The effects of violating standard item writing principles on tests and students: The consequences of using flawed test items on achievement examinations in medical education. Advances in Health Sciences Education. 2005; 10: 133-143. PMid:16078098 https://doi.org/10.1007/s10459-004-4019-5

[11] Vyas R, Supe A. Multiple choice questions: a literature review on the optimal number of options. Natl Med J India. 2016; 21(3): 130-3.

[12] Tarrant M, Ware J. A framework for improving the quality of multiple-choice assessments. Nurse Educ. 2012; 37(3): 98-104 
PMid:22513766 https://doi.org/10.1097/NNE.0b013e3182 $5041 \mathrm{~d} 0$

[13] Reynolds CR, Livingston RB, Wilson V. Measurement and Assessment in Education, Pearson Education, Boston, MA. 2006; 188-203.

[14] Coughlin PA, Featherstone CR. How to Write a High Quality Multiple Choice Questions (MCQ): A Guide for Clinicians. European Journal of Vascular and Endovascular Surgery. 2017; 54(50): 654658. PMid:28870436 https://doi.org/10.1016/j.ejvs. 201 7.07 .012

[15] Al-Rukban MO. Guidelines for the construction of multiple choice questions tests. J Family Community Med. 2006; 13(3): 125-133.

[16] Anderson J. Multiple-choice questions revisited. Med Teach. 2004; 26(2): 110-3. PMid:15203517 https://doi .org/10.1080/0142 159042000196141

[17] Guidelines for the Development of High Quality Multiple Choice Questions. The Pakistan College of Physicians and Surgeons. 2003.

[18] World Health Organization. Nurse educator core competencies. WHO Document Production Services, Geneva, Switzerland. 2016; 6-52.

[19] Brunt BA. Competencies for Staff Educators: Tools to Evaluate and Enhance Nursing Professional Development. HCPro, Inc. 2007.

[20] Brent A, Bauer, MD. Herbal Therapy: What a Clinician Needs to Know to Counsel Patients Effectively. Nurse Education Today. 2005; 80(6): 828.

[21] Guidelines for Transitional Education Plan Preparation. Global Partnership for Education. 2016; 4-36.

[22] Scheerens J. Fundamentals of Educational Planning; improving school effectiveness. United Nations Educational, Scientific and Cultural Organization. 2000; 9-128.

[23] Scheerens J. School Effectiveness Research. International Encyclopedia of the Social \& Behavioral Sciences. 2015; 21: 80-85 https://doi .org/10.1016/B978-0-08-097086-8.92080-4

[24] Rosner B. Fundamentals of Biostatistics: Solutions Manual. 5th ed. 1999.

[25] Coffman J, Rencis JJ, Jensen DJ, et al. Development and Assessment of a Multiple-Choice Quiz for a Bending Stress Quiz. Midwest Section Conference of the American Society for Engineering Education. 2010; $1-22$

[26] Cayo RN, Laughlin D, Rus L, et al. Assessment of Item-Writing Flaws in Multiple-Choice Questions. Journal for Nurses in Professional Development. 2013; 29(2): 52-57. PMid:23657034 https: //doi.org/10.1097/NND.0b013e318286c2f1

[27] Tarrant M, Knierim A, Hayes SK, et al. Thefrequency of item writing flaws in multiple-choice questionsused in high stakes nursing assessments. Nursing Education in Practice. 2006; 6: 354-363. PMid:19040902 https://doi.org/10.1016/j.nepr. 2006.07 .002

[28] Omar AA, Abdulrahim ME, Albalawi IA. Flawed multiple-choice questions put on the scale: What is their impact on students' achievement in a final undergraduate surgical examination? Journal of Health Specialties. 2016; 4(4): 270-75. https://doi .org/10.4103/24 68-6360. 191908

[29] Hijji BM. Flaws of Multiple Choice Questions in TeacherConstructed Nursing Examinations: A Pilot Descriptive Study. Journal of Nursing Education. 2017; 56(8): 490-496. PMid:28787072 https://doi.org/10.3928/01484834-20170712-08

[30] Tarrant M, Ware J. Impact of item-writing flaws in multiple-choice questions on student achievement in high-stakes nursing assessments.
Blackwell Publishing Ltd, Medical Education. 2008; 42: 198-206. PMid:18230093 https ://doi.org/10.1111/j.1365-2923.20 07.02957.x

[31] DiBattista D, Sinnige-Egger JA, Fortuna G. The "None of the Above" Option in Multiple-Choice Testing: An Experimental Study. The Journal of Experimental Education. 2014; 82(2). https : //doi . or $\mathrm{g} / 10.1080 / 00220973.2013 .795127$

[32] Elhassan M, Suliman RA, Gaffar AM. Constructing a-type multiple choice questions (MCQs): step by step manual. Blueprints in Health Profession Education Series. 2011; 5-22.

[33] Miller GE. The assessment of clinical skills/competence/performance. Acad Med. 1990; 87(7): S63-S67. https://doi.org/10.1097/ 00001888-199009000-00045

[34] MD program, University of Toronto. Writing Effective Multiple Choice Questions (MCQ): Working Draft Dec. 20, 2016, Guidelines for faculty who are creating MCQs for the assessment of medical students. MD program, University of Toronto. 2016; 1-10.

[35] Mukherjee P, Lahiri SK. Analysis of Multiple Choice Questions (MCQs): Item and Test Statistics from an assessment in a medical college of Kolkata, West Bengal. IOSR Journal of Dental and Medical Sciences. 2015; 14(12): 47-52.

[36] Chiavaroli NG. Negatively-worded multiple choice questions: An avoidable threat to validity. Researche Gate. 2017; 22(3): 1-14.

[37] Brame C. Writing Good Multiple Choice Test Questions. Teaching center, Vanderbilt University; 2013. Available from: https://cft.vanderbilt.edu/guides-sub-pages/writi ng-good-multiple-choice-test-questions/

[38] Jovanovska J. Designing effective multiple-choice questions for assessing learning outcomes. Infotheca. 2018; 18(1): 25-42. https : //doi.org/10.18485/infotheca.2018.18.1.2

[39] Collins J. Education Techniques for Lifelong Learning Writing Multiple-Choice Questions for Continuing Medical Education Activities and Self-Assessment Modules. RadioGraphics. 2006; 26(2): 543551. PMid:16549616 https://doi.org/10.1148/rg. 2620551 45

[40] Schuwirth L, Pearce J. Determining the quality of assessment items in collaborations: aspects to discuss to reach agreement. the Australian Medical Assessment Collaboration (AMAC); 2014. Available from: https://www.acer.edu.au/amac/resources

[41] Abdulghani HM, Irshad M, Haque S, et al. Effectiveness of longitudinal faculty development programs on MCQs items writing skills: A follow-up study. Open Access PLOS ONE. 2017; 1-14. PMid:29016659 https://doi.org/10.1371/journal.pone.0 185895

[42] Baig M, Ali SK, Ali S, et al. Evaluation of Multiple Choice and Short Essay Question items in Basic Medical Sciences. Pakistan Journal of Medical Science. 2014; 30(1): 3-6.

[43] Nassar MF. Continuing Professional Development in the Healthcare Sector in Egypt: A Readiness Assessment. Published Master Thesis. The American University in Cairo, Egypt. 2017; 10-28.

[44] Criteria and Analysis of Multiple-Choice Questions in Undergraduate Dental Examinations. Journal of Dental Research and Review. 2018; 5(2): 9-64. https://doi.org/10.4103/jdrr.jdrr_30_18

[45] Hui Xu J. Toolbox of teaching strategies in nurse education. Chinese Nursing Research. 2016.

[46] World Health Organization. Nurse educators core competences. World Health Organization. 2016; 1-66. 